Acta Technologica Agriculturae 2

Nitra, Slovaca Universitas Agriculturae Nitriae, 2016, pp. 29-32

\title{
CORROSION RESISTANCE OF GALVANIZED STEEL IN THE ENVIRONMENT OF A BIOREACTOR
}

\author{
Michal ŠUSTR*, Petr DOSTÁL, Jaroslav ZAČAL \\ Mendel University in Brno, Czech Republic
}

\begin{abstract}
The article deals with monitoring the corrosion resistibility of welded materials in the anaerobic fermenter (bioreactor). The main goal of this research is to assess the change of hardness after degradation. The change of hardness occurs in the corrosion environment and it correlates with the corrosion resistibility of material. The purpose of this experiment is to recognize the possibilities of using the CMT welded materials in the defined environment. As an innovative technology the acoustic emission method is used for assessment of surface layer disruption during hardness testing. Aluminium alloy with galvanized steel (AluZinc) was used as an experimental material. The basic materials were welded by the filler material AISi3.
\end{abstract}

Keywords: galvanized steel; galvanic corrosion; hardness measurement; CMT welding; bioreactor; acoustic emission

A bioreactor may refer to any manufactured or engineered device or system that supports a biologically active environment (IUPAC, 2006). The bioreactor is a vessel in which the chemical process is carried out, which involves organisms or biochemically active substances derived from such organisms. This process can either be aerobic or anaerobic. These bioreactors are commonly cylindrical, ranging in size from litres to cubic metres, and are often made of stainless steel. Innovative technologies use modern materials for improving the ecologic and economic parameters of processes. Therefore, there is solved the special welding technology of two different materials in this research.

The purpose is to evaluate whether the materials welded by CMT (cold metal transfer) are suitable for this environment. Important is corrosion resistibility which can be measured by many ways. The attention in this project is paid to the change of hardness after corrosion degradation. It is generally known that the combination of different materials causes galvanic corrosion. This corrosion depends on the environment. Tests reveal the aggressiveness of the bioreactor environment for the galvanic corrosion of used materials (Černý, 2014).

Galvanic corrosion refers to corrosion damage induced when two dissimilar materials are coupled in a corrosive electrolyte. When a galvanic couple forms, one of the metals in the couple becomes the anode and corrodes faster than it would all by itself, while the other becomes the cathode and corrodes slower than it would alone.

For galvanic corrosion to occur, three conditions must be present:

- electrochemically dissimilar metals must be present;

- these metals must be in electrical contact;

- the metals must be exposed to an electrolyte.

The relative nobility of a material can be predicted by measuring its corrosion potential. The well-known galvanic series lists the relative nobility of certain materials in the sea water. A small anode/cathode area ratio is highly undesirable. In this case, galvanic current is concentrated onto a small anodic area. Rapid thickness loss of the dissolving anode tends to occur under these conditions. Galvanic corrosion problems should be solved by designing to avoid these problems in the first place (Dostál and Černý, 2010).

Galvanic corrosion cells can be set up on the macroscopic level or on the microscopic level. On the microstructural level, different phases or other microstructural features can be subject to galvanic currents.

\section{Material and methods}

\section{Experimental material}

The experimental material used for this testing is a weldment of aluminium alloy EN AW 7075 and galvanized steel DX51D. The AluZinc layer thickness is $30 \mu \mathrm{m}$. Dimensions are apparent in Figure 1.

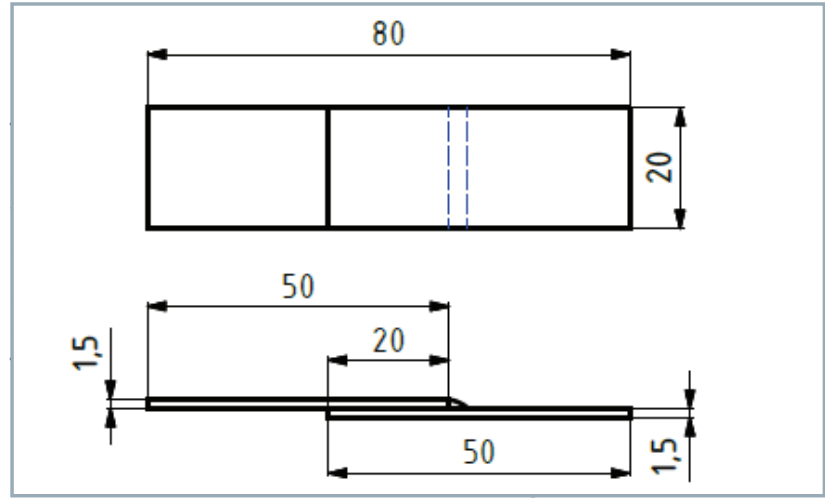

Figure 1 Specimen dimensions 


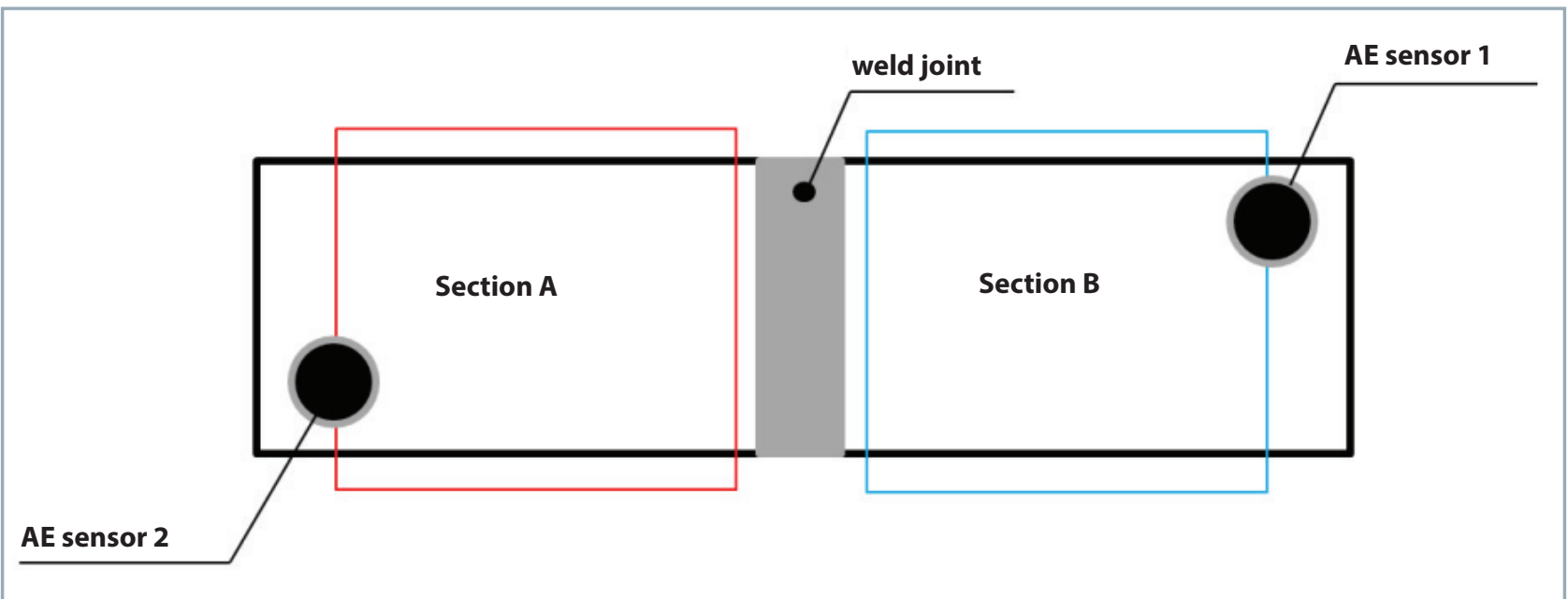

Figure 2

Acoustic emission sensors placement

The surface hardness of galvanized steel was tested according to the HRB method. The response of tested material to the pressure caused by a scleroscope was measured during collecting the data of hardness.

\section{Assessment by means of acoustic emission}

The process of pushing the globule to the material was monitored by the non-destructive testing method acoustic emission (AE). The specimens were equipped with two acoustic sensors IDK-09 connected to a DAKEL XEDO system. Figure 2 schematically

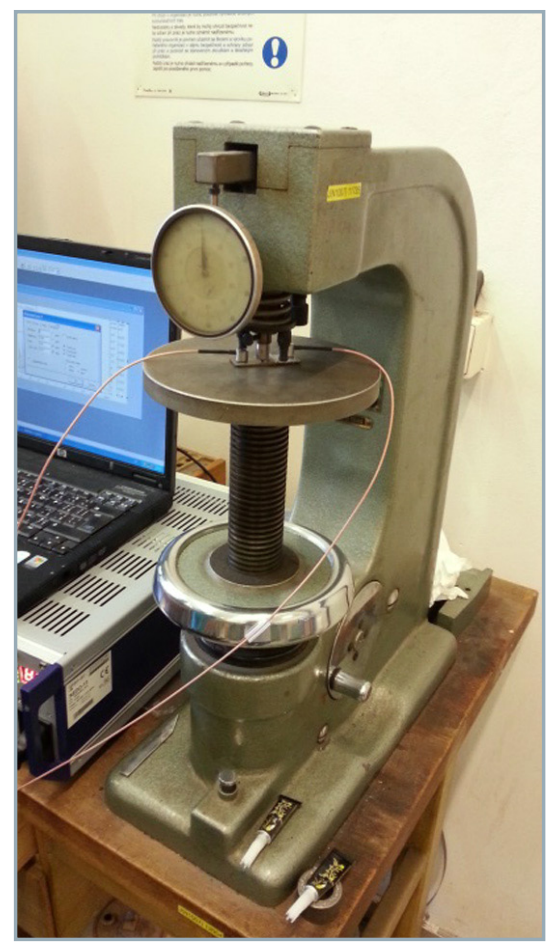

Figure $\mathbf{3}$ Testing system illustrates the locations of $A E$ sensors fitted on the specimen.

Acoustic emission means the physical effect during which it is possible to observe acoustic signals broadcasted by the mechanical, heat or chemical subjected by the solid and it also includes diagnostic method based on this effect. Acoustic emission is performed in the source of acoustic emission during the energy disengaging caused by inner and outer powers (Horák et al., 2010; Dostál and Communeau, 2014).

The acoustic emission formation is generated by non-reversible dislocated and degradation processes in the material microstructure and macrostructure, also by cavity processes in hydro-dynamical systems, by the turbulence during the pipeline liquid fading, dielectric degeneration, etc. Energy is transformed to mechanical tension impulse. This impulse is dilating through the material

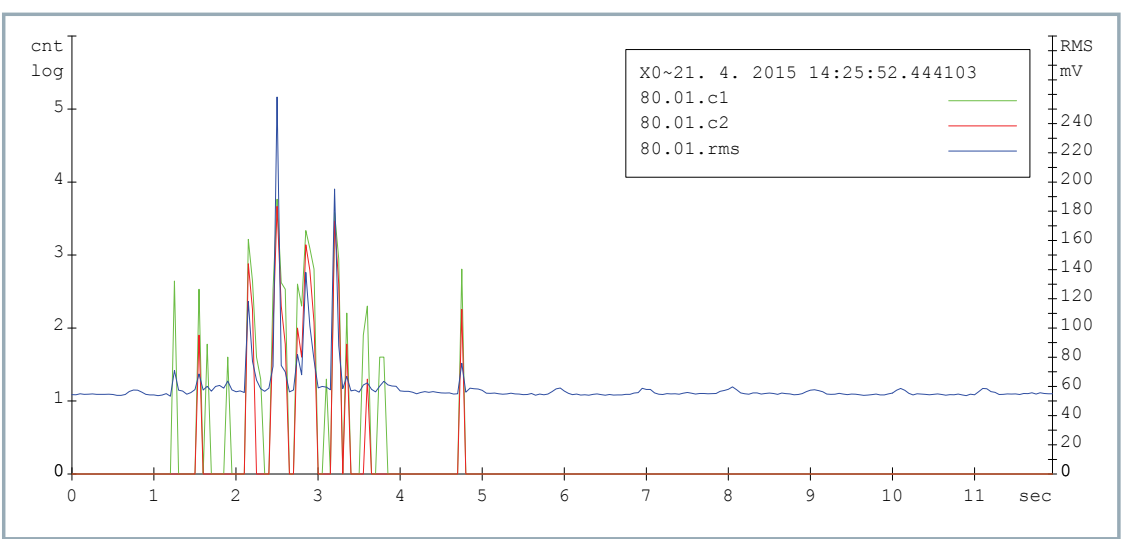

Figure 4 Section A monitoring - before corrosion degradation - hardness $49 \mathrm{HRB}$ such as elastic tension longitudinal or transverse wave (Dostál and Černý, 2010; Dostál et al., 2011).

Figure 3 illustrates the testing system with the specimen placed in the measuring device. On the surface of the specimen, there are visible the acoustic sensors which are connected to the assessment centre.

\section{Results and discussion}

There were 40 verification measurements in two parts of tested samples. Table 1 shows the arithmetic average of measured hardness values HRB. There are compared the values of specimen before and after corrosion degradation in the bioreactor environment. The sections A, B are visible in Figure 2.

The hardness of the AluZinc anticorrosive layer decreases due to the corrosion environment, facts based 
Table 1 Arithmetic average of measured hardness values

\begin{tabular}{|c|c|c|c|c|}
\hline \multirow[t]{2}{*}{ Section } & \multicolumn{2}{|c|}{ Hardness after corrosion degradation } & \multicolumn{2}{|c|}{ Hardness before corrosion degradation } \\
\hline & hardness HRB & average & hardness HRB & average \\
\hline \multirow{10}{*}{ A } & 48 & \multirow{10}{*}{45.2} & 45 & \multirow{10}{*}{46.4} \\
\hline & 39 & & 47 & \\
\hline & 47 & & 47 & \\
\hline & 45 & & 46 & \\
\hline & 44 & & 48 & \\
\hline & 44 & & 44 & \\
\hline & 50 & & 46 & \\
\hline & 46 & & 47 & \\
\hline & 44 & & 48 & \\
\hline & 45 & & 46 & \\
\hline \multirow{10}{*}{ B } & 42 & \multirow{10}{*}{41.4} & 46 & \multirow{10}{*}{46.5} \\
\hline & 41 & & 48 & \\
\hline & 41 & & 46 & \\
\hline & 42 & & 46 & \\
\hline & 40 & & 46 & \\
\hline & 39 & & 47 & \\
\hline & 42 & & 46 & \\
\hline & 42 & & 47 & \\
\hline & 43 & & 46 & \\
\hline & 42 & & 47 & \\
\hline
\end{tabular}

on literature (Hiroshi, 1997; Černý and Dostál, 2014). Material was affected mainly by point corrosion and pitting corrosion (Talbot and Talbot, 2010). The decrease of corrosion resistance measured by the decrease of hardness is $7.8 \%$ in average.

Each measurement included continual acoustic emission scanning. The reason is an innovative monitoring of the surface layer corrosion and

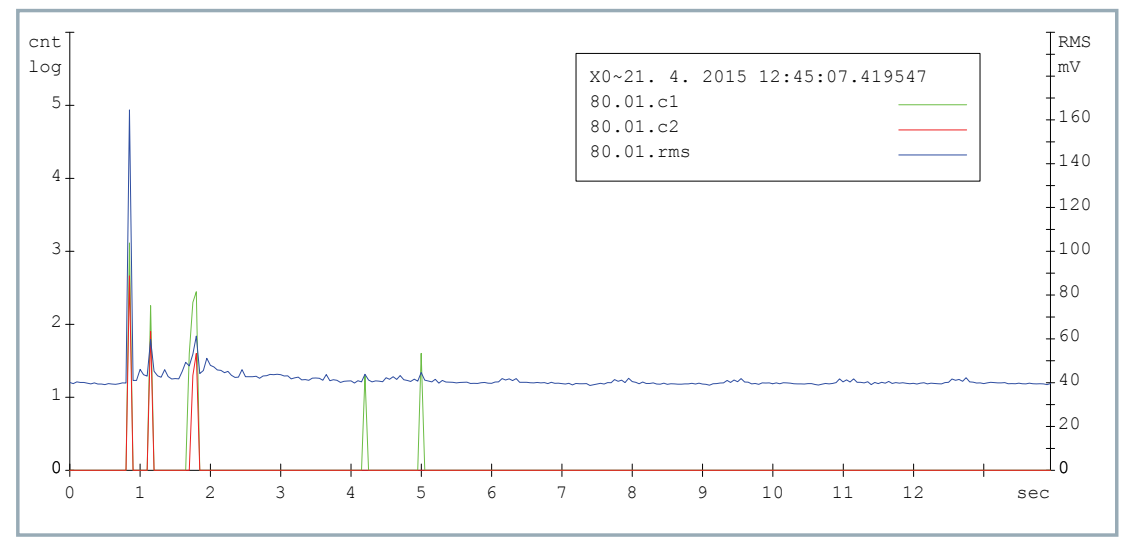

Figure 5

finding connections between the decrease of hardness and acoustic feedback.

Figure 4 shows the acoustic response during hardness testing in the section $A$ on the specimen before corrosion degradation. The value of the maximum RMS (Root Mean Square) takes $280 \mathrm{mV}$. This high activity is caused by eminent quality, rigidity and hardness of the tested layer which is

Section A monitoring - after corrosion degradation - hardness 44 HRB not corroded. There is obvious a rapid destruction of the surface layer. This destruction can be comparable with fragile material brakeage, based on literature (Hiroshi, 1997; Horák et al., 2010).

In Figure 5 there is recorded the acoustic response of the same section A on the specimen after corrosion degradation. There is visible the value of the maximum RMS, which is $180 \mathrm{mV}$. The acoustic emission activity, which is correlating with lowered hardness, can be registered. This decline can be explained by microscopic connecting of corrosive point and dents.

The logarithm of counts is on the left vertical axis, voltage in millivolts is on the right vertical axis. The time of testing is on the horizontal axis.

Figures 6 and 7 show the acoustic response before and after corrosion degradation in the section $B$, see Figure 2. Those records confirm the previous records from the section $A$. There is obvious that the specimen before corrosion degradation is 


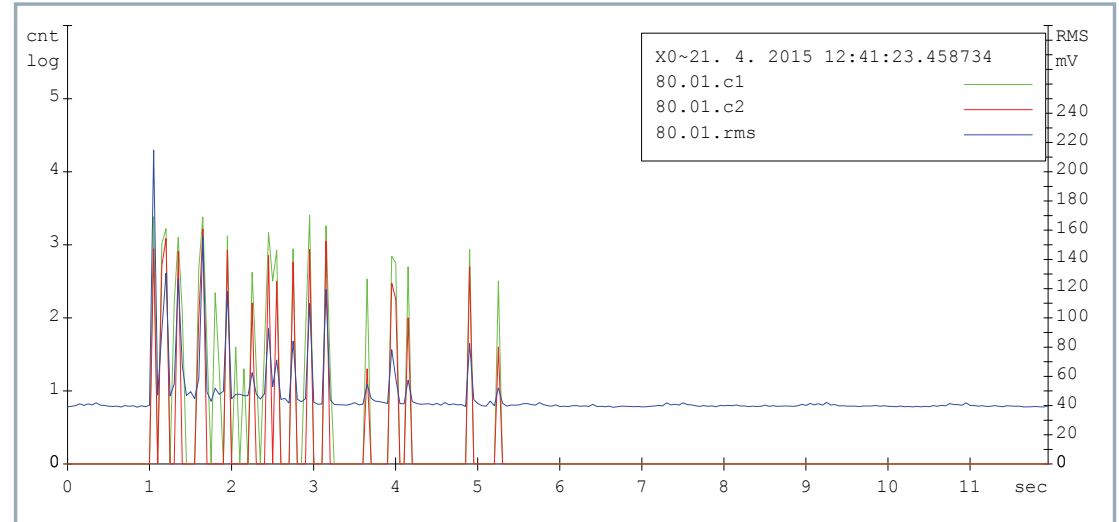

Figure 6 Section B monitoring - before corrosion degradation - hardness $50 \mathrm{HRB}$

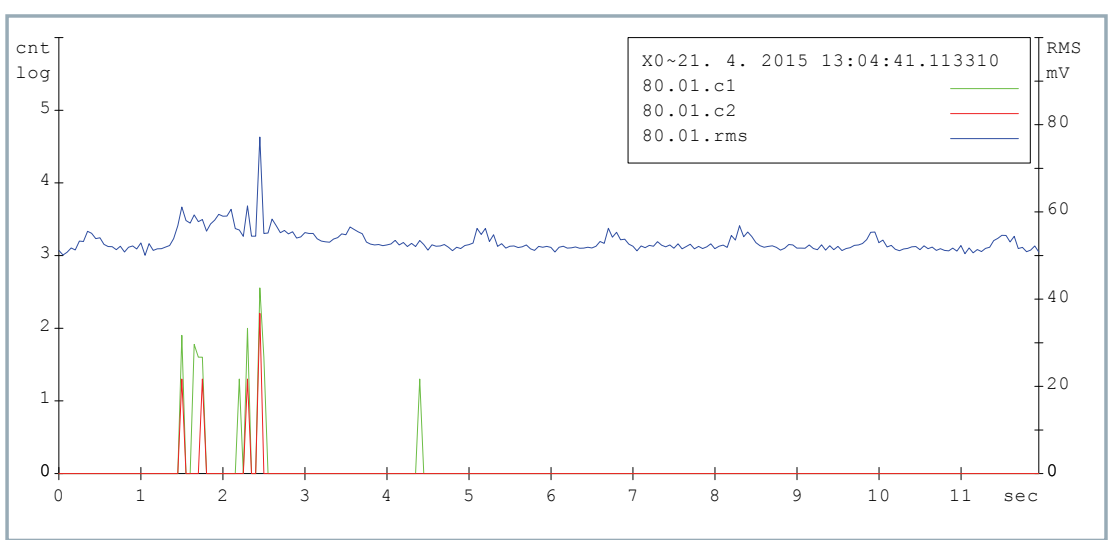

Figure 7 Section B monitoring - after corrosion degradation - hardness 43 HRB

characterized by stronger acoustic response in comparison with the specimen after corrosion degradation.

\section{Conclusion}

A new period of advanced materials brings new possibilities for their use. At the same time, materials can combine sophisticated welding methods. It is necessary to seek applications for the improvement of economy and ecology. The latest materials and technology have to be used for being competitive. This is the reason for materials usability testing in given environments. This study analysed the hardness decrease of the material surface layer. This is in direct relation to the decrease in corrosion resistance.

An innovative approach to solutions is demonstrated in this project, mainly the use of acoustic emission as a tool for monitoring the decline in the quality of the material. The research results are applicable to engineering practice in the field of using new materials in the bioreactor environment.

\section{Acknowledgement}

The research has been supported by the project IP 10/2015 'Degradation properties of welded joints' financed by IGA AF MENDELU.

\section{References}

IUPAC. 2006. Compendium of Chemical Terminology. $2^{\text {nd }}$ ed. The 'Gold Book': 1997. Online corrected version: 2006.

ČERNÝ, M. 2014. Adhesion of zinc hot-dip coatings. In Acta Universitatis Agriculturae et Silviculturae Mendelianae Brunensis, vol. 62, 2014, no. 1, pp. 53-64.

ČERNÝ, M. - DOSTÁL, P. 2014. Adhesion of zinc hot-dip coatings. In Acta Universitatis Agriculturae et Silviculturae Mendelianae Brunensis, vol. 62, 2014. no. 1, pp. 53-64.

DOSTÁL, P. - COMMUNEAU, P. 2014. Visualisation of corrosion acoustic signals using quality tools. Source of the document. In Acta Universitatis Agriculturae et Silviculturae Mendelianae Brunensis, vol. 62, 2014, no. 1, pp. 65-69.

DOSTÁL, P. - ČERNÝ, M. 2010. Monitoring akustické emise při mechanické a korozní degradaci. In Proceedings of International Ph.D. Students Conference. Brno: Mendelova univerzita v Brně, 2010. pp. 497- 506.

DOSTÁL, P. - ČERNÝ, M. - VARNER, D. 2011. Proportional monitoring of the acoustic emission in crypto-conditions. In Acta Universitatis Agriculturae et Silviculturae Mendelianae Brunensis, vol. 57, 2011, no. 5, pp. 31-38.

HIROSHI, K. 1997. Pitting Corrosion Behavior of Stainless Steels in Atmospheric Environments, 1997. pp. 153-160.

HORÁK, K. - ČERNÝ, M. - FILÍPEK, J. - FAJMAN, M. 2010. Tepelná a mechanická odolnost zinkového povlaku. In Acta Universitatis Agriculturae et Silviculturae Mendelianae Brunensis, vol. 58, 2010, no. 4, pp. 49-56.

TALBOT, D. E. J. - TALBOT, J. D. R. 2010. Corrosion Science and Technology, 2010. 432 pp. ISBN 978-14-2004-988-6. 